\title{
Relationship between Ethyl Methanesulphonate Concentration and Immersion Interval, and Germination and Seedling Vigor in Oats ${ }^{1}$
}

\author{
R. Abrams and K. J. Frey ${ }^{2}$ \\ INTRODUCTION
}

The prime problem encountered when a mutagen is used on a plant species for the first time is to determine the appropriate dosage. This problem is further complicated because so many other factors, such as the moisture content of the treated seed $(1,3,5,12)^{3}$, characteristics of the atmosphere $(3,5,12)$, seed covering $(6)$, seed size $(6)$, and genotype $(1,12)$ influence the degree of mutagen effect upon the seed germination, $\mathrm{M}_{1}{ }^{4}$ seedling survival, uniformity and sterility, and frequency of chromosomal aberrations and mutations.

Some of the criteria used to assay the effects of the mutagen treatment upon seed are germination percentage and $M_{1}$ seedling height, relative to the untreated check. This paper reports data from experiments conducted to determine the effects of varying doses of ethyl methanesulphonate, a strong mutagen $(10,11)$, upon the $\mathrm{M}_{1}$ generation of hexaploid oats.

\section{MATERIALS AND METHODS}

Two experiments were conducted in the greenhouse at Ames, Iowa, in which primary oat seed of the variety Clintland 60 were treated with ethyl methanesulphonate ${ }^{5}$ at varying concentrations and immersion intervals. In experiment 1, 400 seed lots were immersed in water and in EMS solutions of 0.04-, 0.08-, and 0.12-mol concentrations for 2- and 24-hour intervals at room temperature. In experiment 2, two concentrations, 0.04 and $0.12 \mathrm{~mol}$, and two immersion intervals, 2 and 4 hours, were used. After treatment the seed were rinsed with tapwater and immediately planted 1/2-inch deep in flats containing a soil mixture of loam, sand, and peat in the ratio of $2: 1: 1$.

The experimental design was a randomized block with four replications

1 Journal Paper No. J-4676 of the Iowa Agricultural and Home Economics Experiment Station, Ames, Iowa; Project No. 1176.

2 Formerly graduate student, Iowa State University, now Associate Plant Breeder, Agricultural Experiment Station of Puerto Rico, Isabela, P.R.; and Professor of Farm Crops, Iowa State University, Ames, Iowa, respectively.

3 Italic numbers in parentheses refer to Literature Cited, pp. 310-1.

${ }^{4} \mathrm{M}_{1}$ refers to the plants grown from seed treated with a mutagen.

5 Ethyl methanesulphonate will be abbreviated herein to EMS. 
for experiment 1 and two replications for experiment 2. A plot consisted of 100 seed planted in a row across a flat ( 22 inches). The plots were spaced 2 inches apart so that each flat contained eight plots. The experiments were conducted in the greenhouse. Germination percentages and mean seedling heights were recorded on a plot basis 14 days after planting.

\section{EXPERIMENTAL RESULTS}

The mean germination percentages and $M_{1}$ seedling heights for oatseed lots in experiment 1 are presented in table 1. Soaking the seed for 2 hours in 0.04-, 0.08-, and 0.12-mol EMS solutions did not reduce germination significantly, but there was a tendency toward lower germination with an increased concentration of EMS. The 24-hour immersion interval killed

TABLE 1.-Mean germination percentages and $M_{1}$ seedling heights from seed lots of Clintland 60 oat variety after treatment with 3 concentrations of EMS, using 2 immersion intervals in experiment 1

\begin{tabular}{c|c|c}
\hline Treatment & Germination' & Seedling height \\
\hline & Percent & $M m$. \\
Check & $95^{\mathrm{a}}$ & $27^{\mathrm{a}}$ \\
0.04 mol for 2 hours & $96^{\mathrm{a}}$ & $25^{\mathrm{b}}$ \\
.08 mol for 2 hours & $93^{\mathrm{a}}$ & $24^{\mathrm{b}}$ \\
$.12 \mathrm{~mol}$ for 2 hours & $86^{\mathrm{a}}$ & $22^{\mathrm{c}}$ \\
.04 mol for 24 hours & $33^{\mathrm{b}}$ & $17^{\mathrm{d}}$ \\
\hline
\end{tabular}

1 Means with the same letter superscript belong to the same significance group according to Duncan's multiple-range test (14).

all seed soaked in 0.08- and 0.12-mol solutions of EMS, and seed germination was reduced to 33 percent by 0.04 -mol level.

Each of the EMS solutions caused a significant reduction in $\mathrm{M}_{1}$ seedling height. The 2-hour immersion of oat seed in the 0.04 - and 0.08 -mol solutions caused a 10-percent reduction in seedling height. A similar treatment in the 0.12-mol solution caused a 20-percent reduction, and a 24-hour immersion in the 0.04-mol solution caused a 40-percent reduction in $\mathrm{M}_{1}$ seedling height.

In experiment 2 (table 2) each of the treatment combinations, with the exception of the 2-hour immersion in the 0.04-mol EMS solution reduced the germination percentage significantly, and all of the treatments reduced seedling height by 25 and 30 percent, respectively.

The reductions in germination percentage and seedling height from the treatment of oat seed with 0.12-mol EMS solution for 4 hours were similar to those resulting from the thermal-neutron treatment applied in some mutation breeding studies (1.4-2.0 $\times 10^{13}$ neutrons per square centimeter) ${ }^{6}$

- Unpublished data from Iowa Agriculture and Home Economics Experiment Station. 


\section{SUMMARY}

Seed of Clintland 60 variety of oats were immersed for 2- and 24-hour intervals in water and in EMS solutions of 0.04-, 0.08-, and 0.12-mol strength, and for 2- and 4-hour intervals in 0.04- and 0.12-mol solutions. None of the EMS concentrations reduced germination percentages or seedling heights markedly when the immersion interval was 2 hours. However, the 24-hour immersion was lethal, with the 0.08 - and 0.12 -mol solutions, and reduced germination percentage to 33 with the $0.04-\mathrm{mol}$ solution. Reduction in germination percentage and seedling height after treatment with 0.12 -mol EMS solution for 4 hours closely approximated the $\mathrm{M}_{1}$ damage for treating oat seed with 1.4-2.0 $\times 10^{13}$ neutrons per square centimeter.

TABLE 2.-Mean germinalion percentages and seedling heights from seed lots of Clintland 60 oat variety after treatment with 2 concentrations of EMS, using $\&$ immersion intervals in experiment 2

\begin{tabular}{c|c|c}
\hline \multicolumn{1}{c|}{ Treatment } & Germination $^{1}$ & Seedling height \\
\cline { 2 - 3 } Check & Percent & $M \mathrm{~m}^{\mathrm{a}}$ \\
$0.04 \mathrm{~mol}$ for 2 hours & $99^{\mathrm{a}}$ & $20^{\mathrm{a}}$ \\
$.04 \mathrm{~mol}$ for 4 hours & $91^{\mathrm{a}}$ & $18^{\mathrm{b}}$ \\
$.12 \mathrm{~mol}$ for 2 hours & $86^{\mathrm{b}}$ & $18^{\mathrm{b}}$ \\
$.12 \mathrm{~mol}$ for 4 hours & $85^{\mathrm{b}}$ & $17^{\mathrm{b}}$ \\
& $75^{\mathrm{c}}$ & $14^{\mathrm{c}}$ \\
\hline
\end{tabular}

${ }^{1}$ Means with the same letter superscript belong to the same significance group according to Duncan's multiple-range test (14).

\section{RESUMEN}

Semillas de la variedad de avena Clintland 60 se sumergieron por un período de 2 y 24 horas en soluciones de EMS a concentraciones de 0.04, 0.08 y $0.12 \mathrm{~mol}$ y también durante un período de 2 y 4 horas en soluciones de 0.04 y $0.12 \mathrm{~mol}$. Ninguna de las concentraciones de EMS redujo marcadamente los porcentajes de germinación, ni el tamaño de las plántulas cuando el período de inmersión de la semilla fue de 2 horas. Sin embargo, una inmersión por 24 horas fue letal a las semillas en las concentraciones de 0.08 y $0.12 \mathrm{~mol} \mathrm{y}$ el porcentaje de germinación se redujo un 33 con la solución $0.04 \mathrm{~mol}$. La reducción en el porcentaje de germinación y altura de las plántulas, después de tratarse con una solución de EMS a una concentración de 0.12 -mol por 4 horas, se aproxima bastante al daño causado en la $M_{1}$ de semillas de avena sometidas a una dosis de 1.4-2.0 $\times$ $10^{13}$ neutrones por centímetro cuadrado.

\section{LITERATURE CITED}

1. Abrams, R., and Frey, K. J., The relationship between moisture content and X-ray sensitivity of oat seeds, Avena sativa, Proc. Iowa Acad. Sci. 64 155-59, 1957. 
2. Abrams, R., Variation in quantitative characters of oats (Avena sativa) after different mutagen treatments, unpublished Ph.D. thesis, Iown State Univ. Library, Ames, Iowa, 1963.

3. Caldecott, R. S., Ionizing radiations and plant breeding. Proc. Intern. Conf. Peaceful Uses Atomic Encrgy, Geneva, 1955, 12 40-5, 1956.

4. Ehrenberg, L., Gustafsson, A., and Lundquist, U., Viable mutants induced in barley by ionizing radiations and chemical mutagens, Heredilas 47 243-82, 1961.

5. Ehrenberg, L., Gustafsson, A., and Nybom, N., Irradiation effects, seed soaking, and oxygen pressure in barley, Heredilas 39 493-504, 1953.

6. González, C. L., and Frey K. J., Effect of sced size and hulls upon X-ray sensitivity of oat seeds, Proc. Iova Acad. Sci. 66 123-8, 1959.

7. Gustafsson, A., Mutations in agricultural plants, Hereditas 33 1-100, 1947.

8. Gustafsson, A., and MacKey, J., The genetical effects of mustard gas substances and neutrons, Heredilas 34 371-86, 1948.

9. Heiner, R. E., Konzak, C. F., Nilan, R. A., and Legault, R. R., Diverse ratios of mutations to chromosome aberrations in barley treated with dietliylsulphate and gamma rays, Proc. Nat. Acad. Sci. 46 1215-21, 1360.

10. Heslot, H., Ferrary, R., Levy, R., and Monard, C., Recherches sur les substances mutagens (halogeno- 2 ethyle) amines, derives oxygenes du sulfures de bis(chloro- 2 ethyle) esters sulfonoques et sulfuriques, Compt. Rend. des Scances Acad. Sci. 248 729-32, 1959.

11. - - - - - - , and - - Induction de mutations chez l'orge: efficacite relative des rayons gamma, du sulfate d'ethyle, du methane sulfonate d'ethyle et de quelques autres substances, in symposium on the Effects of Ionizing Radiations on Seeds and their Significance for Crop Improvements, Effects of ionizing radiations on seeds, pp. 243-47, Kaertnerring, Vienna 1, Austria, Int. AEA, 1961.

12. Konzak, C. F., Genetic effects of radiation on higher plants, Quart. Rev. Biol. 32 27-45, 1957.

13. Konzak, C. F., Nilan, R. A., Legault, R. R., and Heiner, R. E., Modification of induced genetic damage in seeds, in symposium on the Effects of Ionizing Radiations on Seeds and their Significance for Crop Improvements, Effects of ionizing radiations on seeds, pp. 171-8, Kaertnerring, Vienna 1, Austria, Int. AEA, 1961.

14. Le Clerg, F. L., Leonard, W. H., and Clark, A. G., Field plot technique, Burgess Publishing Co., 2nd ed. Minneapolis, Minn., 1962. 